\title{
The Controlling of Deformation Basing on Strain Partitioning Model: Case Study to Gafsa Basin (Southern Tunisian Atlas)
}

\author{
Soulef Amamria1, Mohamed Sadok Bensalem² ${ }^{2}$, Mohamed Ghanmi ${ }^{1}$, Fouad Zargouni ${ }^{1}$ \\ ${ }^{1}$ University of Sciences of Tunisia, University of Tunis El Manar, Tunis, Tunisia \\ ${ }^{2}$ Faculty of Sciences of Gabes, University of Gabes, Erriadh City, Tunisia \\ Email: soulefamamria@gmail.com
}

Received 3 February 2015; accepted 8 March 2015; published 25 March 2015

Copyright (C) 2015 by authors and Scientific Research Publishing Inc.

This work is licensed under the Creative Commons Attribution International License (CC BY). http://creativecommons.org/licenses/by/4.0/

(c) (i) Open Access

\begin{abstract}
One of the principal parameters to study the tectonics deformation is the relation between the shortening axis and the direction of preexistent principal fault. It is important to verify this parameter in the belts structures. The aim of this contribution is to check this notion in the Atlassic structures, especially in the southern limit of Tunisian Atlas: Gafsa fault. The strain partitioning model proposed in the interpretation of geodynamics of Gafsa chains suggests the coexistence of thrusting and strike-slip faults during the same tectonics phase. The application of this model requires a particular geometry between the shortening axis and the direction of fault, and indeed the obliquity of preexistent faults by the reported shortening axis interprets us a transpressive context. The slickenside examination shows the coexistence of thrusting and strike-slip faults. The application of model of strain partitioning requires a decollement level which is confirmed in the Gafsa basin by the upper level of Triassic series. These parameters confirm a particular relation thin and thick-skinned and the maximum of deformation is cover, although the basement structures permeate simple passive transport of the deformation along the Triassic decollement level. These problems confirm the assumption of the evolution of the shortening axis during geological events and especially the rotation of Africa and Eurasia.
\end{abstract}

\section{Keywords}

Strain Partitioning, Gafsa Chains, Triassic Decollement Level, Thin and Tick Skinned

\section{Introduction}

In the North of the African plate, especially in the northern extremity of Atlassic chains, the geological struc-

How to cite this paper: Amamria, S., Bensalem, M.S., Ghanmi, M. and Zargouni, F. (2015) The Controlling of Deformation Basing on Strain Partitioning Model: Case Study to Gafsa Basin (Southern Tunisian Atlas). Journal of Geoscience and Environment Protection, 3, 22-30. http://dx.doi.org/10.4236/gep.2015.31004 
tures underwent an intense geodynamic activity and a very complex structural evolution during the tectonic phases (Decourt et al., 1985 [1]; Morelli and Barrier, 2004 [2]; Frizon de Lamotte et al., 2009 [3]). Martinez et al. (1990) [4] proposed that the evolution of deformation in the Northern of the African plate was correlated with the intense téthysian activity during the tectonic phases.

In Tunisia, rifting activity at the beginning of Mesozoic is associated with the development of orogenic domains controlled by preexistent faults; the south limit of these deformations is the southern atlasique front of Tunisia (Frizon de Lamotte et al., 2000 [5]). The northern African chains especially the Tunisian atlas is the object of several studies. The southern atlas of Tunisia is the limit between two different tectonics domains. This zone is presented by several work (Zargouni et al., 1986 [6]; Ben Ayed, 1986 [7]; Boukadi, 1994 [8]; Bouaziz, 1995 [9]), the folds of Gafsa Basin are characterized by NW-SE direction and have a complicated geometry. The genesis of Gafsa folds is particular for Atlassic chains during compressive Atlassic phase and post Villafran chian (Chihi et al., 1984 [10]; Zargouni et al., 1985 [11]; Boukadi, 1985 [12]). The problem proposed by the major of studies in this zone is the role of tectonics inheritance and reactivation of preexisting faults.

The principal direction of southern Tunisian Atlas is E-W controlled by preexisting faults (Gafsa fault, Bouhedma fault, Orbata fault...), but the particularity of Gafsa folds by the reported major atlassic folds in Tunisia is the NW-SE direction controlled by preexistent faults (Figure 1). The condition of development of Gafsa range is problematic because it's parallel to alpine axis of shortening

Many models are proposed to interpret the geometry of folds in the southern Atlassic limits, but they don't resolve yet the implication of the basement in deformation. For the study, we have interest in the relationship between cover and basement, so we propose a model of evolution of structures during the tectonic phases.

\section{Geodynamics Setting}

Several authors have studied the geometry and kinematic of tectonic structures of the southern central Atlassic of Tunisia based on the evolution of strain during tectonic phases (Zargouni et al., 1985 [11], Ahmadi et al., 2006 [13]). In the same context, Boukadi (1994) [8] proposed a model of pull-appart basin to explain the evolution of structures in North-South axis and the Gafsa chains (Figure 2).

In the North-South axis and southern central of Tunisian Atlas, several models developed the relation between thrusting and strike-slip faults (Perthuisot, 1978 [14]; Zargouni et al., 1985 [11], Creuzot et al., 1993 [15]; Outtani et al., 1995 [16]; Ahmadi et al., 2006 [13]; Ouali, 2007 [17]; Bensalem et al., 2010 [18]; Zouaghi et al., 2011 [19]; Saïd et al., 2011 [20], Amamria et al., 2011 [21]...). We particularly choose three models to control the evolution of deformation in southern central of Tunisian. The choice of these models is related to the distribution of direction of structures of the principal shortening axis.

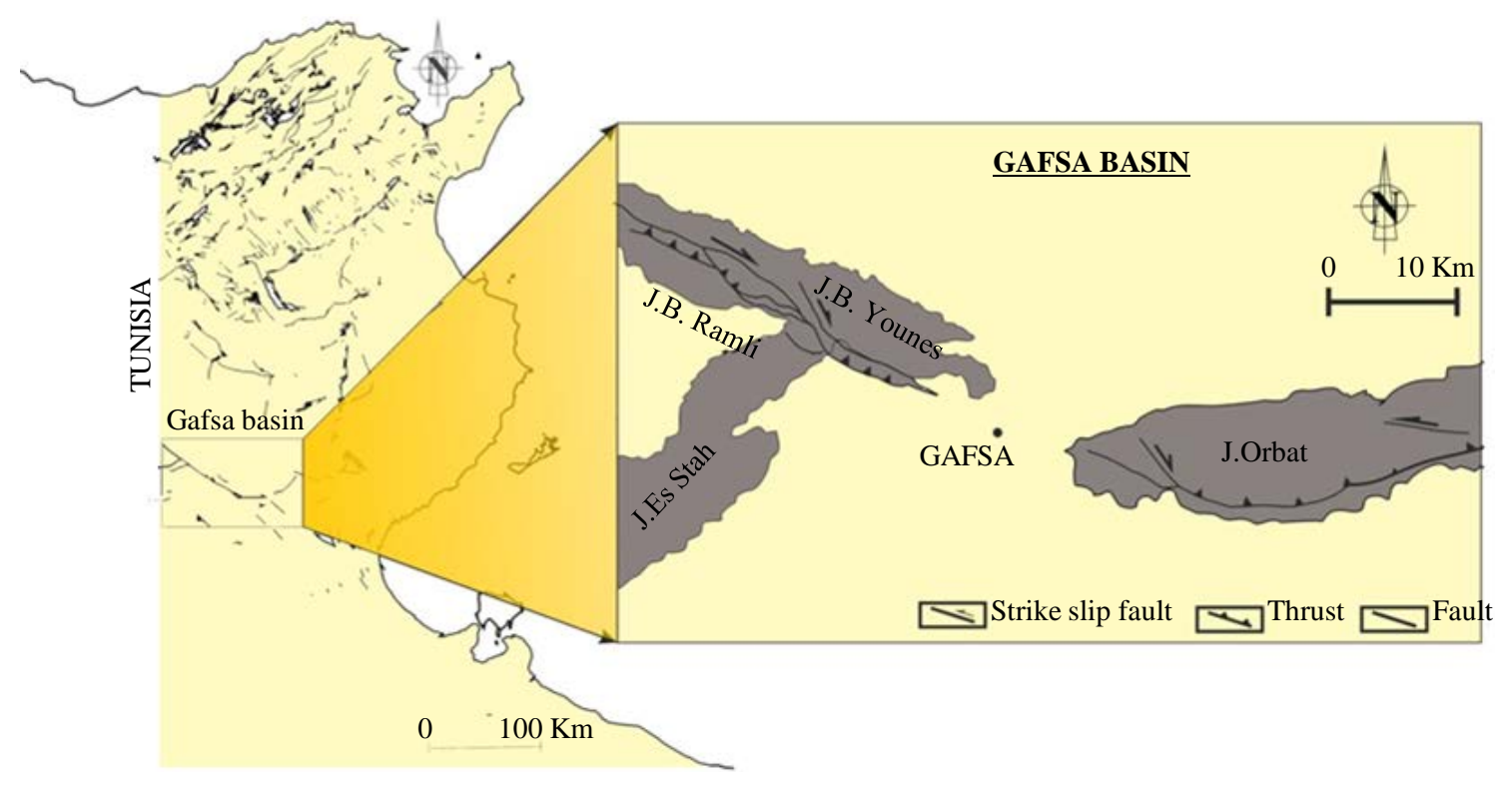

Figure 1. Localization of Gafsa Basin occupied central position of southern-central Tunisian Atlas. 


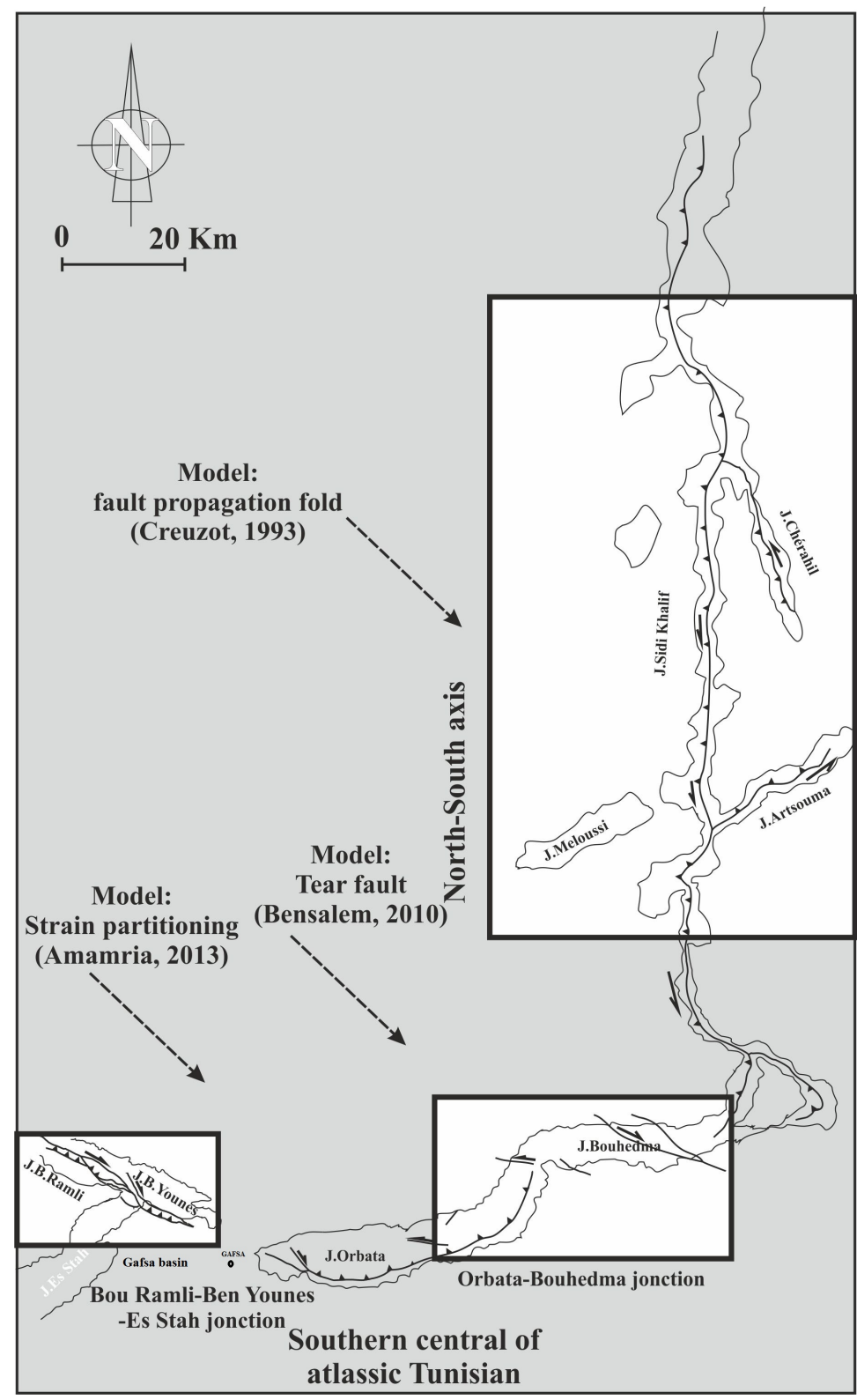

Figure 2. Localization map of different study areas.

Creuzot et al. (1993) [15] proposed the model of fault propagation fold which was developed on a ramp with two edge seams in North-South axis.

Bensalem et al. (2010) [18], based on the notion of tectonic inheritance, interpreted the role of preexisting faults in the evolution of deformation in Orbata-Bouhedma junction. In this study, the strain was always accentuated proportionally in preexistent faults. The conjugate activity of cover faults was observed by the overlapping of folds in form of duplex structures according to the model of tear faults.

Recently we proposed a model of strain partitioning in Gafsa chains that was verified firstly by the coexistence strike-slip faults to the overlapping and secondly by the obliquity of convergence to preexisting faults. The application of this model required the decollement level delimited basement structures to that of cover.

These various models are related to the obliquity of shortening axis during compressive phases to preexisting faults. This shortening axis is delimited from NNW-SSE to NS direction. This direction of shortening corresponds to the evolution of rotation of Africa to Eurasiatic plates (Aissaoui, 1984 [22]; Gourmelen, 1984 [23], Ouali, 1985 [24]; Zargouni, 1985 [25]; Zouari, 1995 [26]; Bensalem et al., 2010 [18]; Amamria et al., 2013 [27]...). 
The evolution of the geometry of the structures is not only related to the direction of the shortening axis to the preexistent faults but also to the implication of the basement in the deformation. It is important thus to study the relation of cover-basement.

\section{Problematic of Implication of the Basement}

Several authors supposed that during compressive tectonic phases, the basement faults are inactive (Outtani et al., 1995 [16]; Addoum, 1995 [28], Ahmadi et al., 2006 [13]). Our study presented the arguments which defended the assumption of the activity of the major faults of the basement that was not retained by these authors, while agreeing with them on the concept of cover deformation or "thin skinned".

In Gafsa Basin, the particularity of Triassic outcrops is their weak thickness, they mark out the preexistent weaknesses. The examination of these weaknesses show the coexistence of the overlapping and the strike-slip faults with a main component is the thrusting (Figure 3).

The basement allows only a simple passive transport of the deformation along a Triassic decollement level while the maximum of deformation in the series of covers. Consequently the Triassic series will be mobilized first of all along the preexistent faults during the distensives phases, and the deformation of cover was taken again during compressive phases. The structural study shows a tectonic style in "thin skinned". This style "thin skinned" is materialized by tectonics of cover and its development of model of fault propagation fold is connected on a Triassic decollement level.

\section{Relation between Thrusting and Strike-Slip Faults}

In basin of Gafsa, the segments of overlapping on the surface recut principal structures with a NW-SE direction. These segments correspond to a great overlapping in subsurface. The transpressive deformation adapted by various structures example of folds and overlapping of variable direction NW-SE to oblique movement example of the faults of FBR 2 and FB 2 and of the major strike-slip faults example of FK 1, FK 2 and FK 3. Whereas, the principal overlapping fault in Gafsa Basin which controls the strain and the genesis of the folds is the result of the passive transport of the movement of the basement. The increase in rate of the deformation is absorbed by the compressive structures, which are oblique compared to the stress field (Figure 4).

The overlapping fault partitioned the oblique convergence during the tectonic phases generating the genesis of the strike-slip faults. Thus, the partitioning of the deformation was under control of the oblique ramp in Gafsa Basin with coexistence of the strike-slip faults associated with the overlapping (Figure 5).

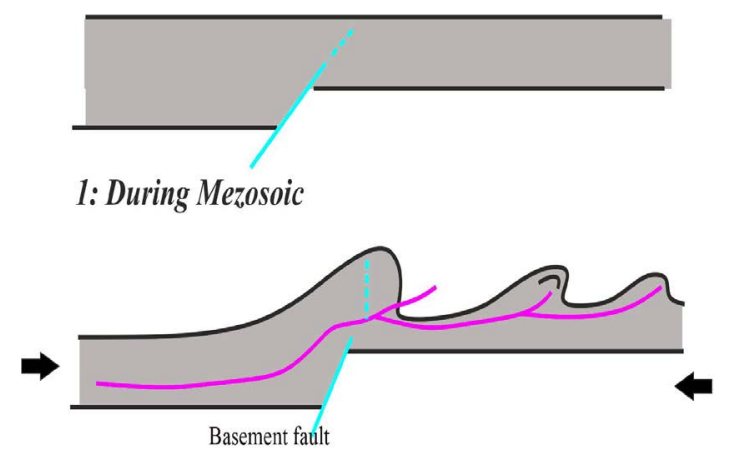

3: During Alpin phases

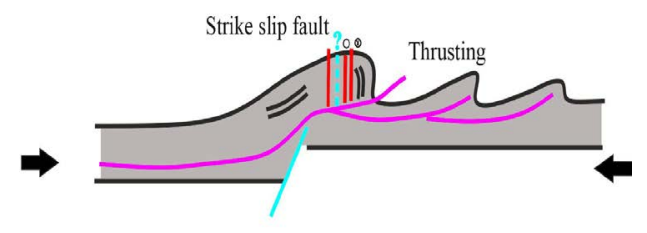

Etape 4: During Post-villafranchian phases

Figure 3. Kinematics of thrusting and strike-slip faults in contact with Triassic decollement level. 


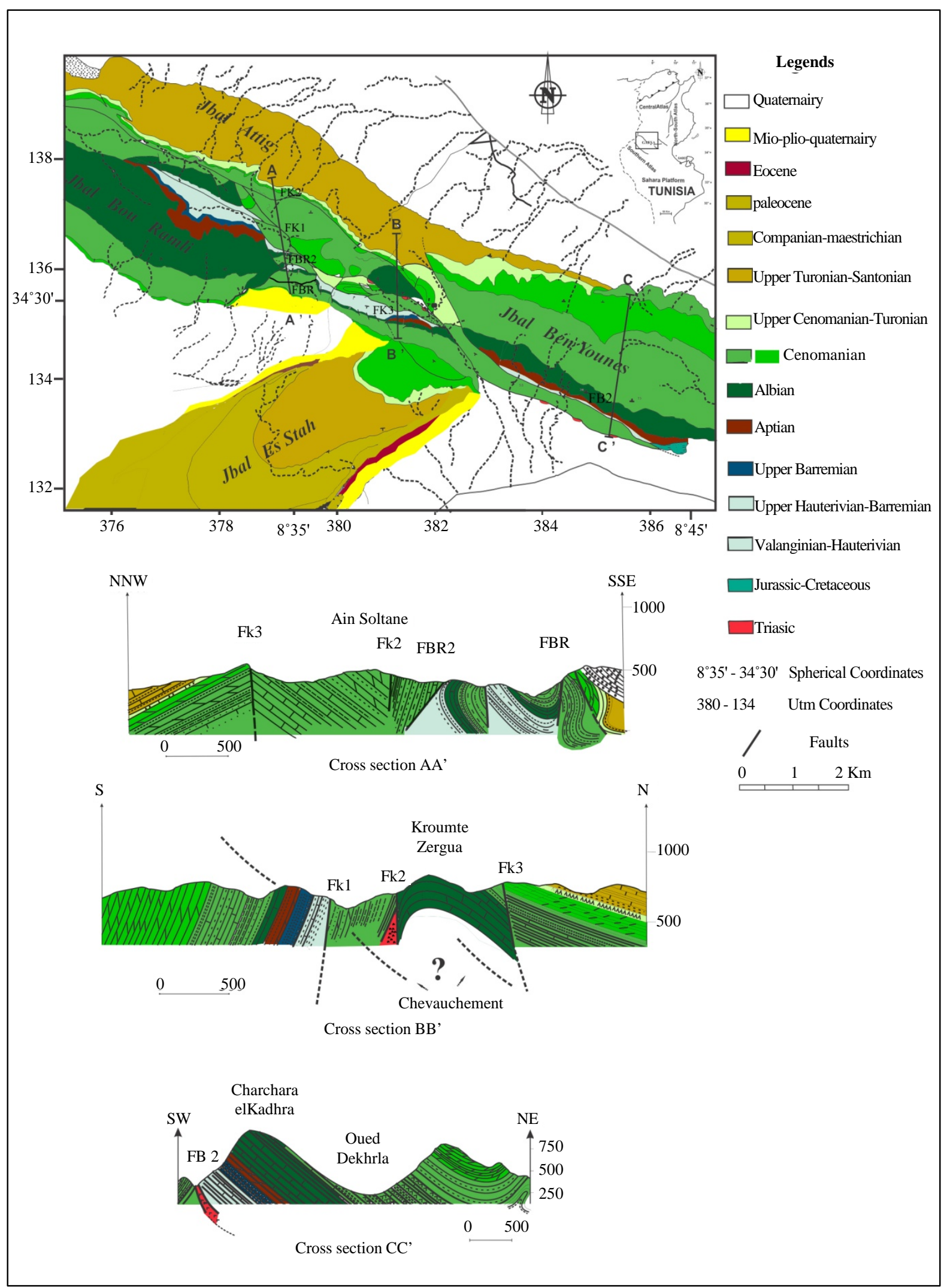

Figure 4. Presentation of the geological cross section which shows the various overlapping faults and strike-slip faults. 


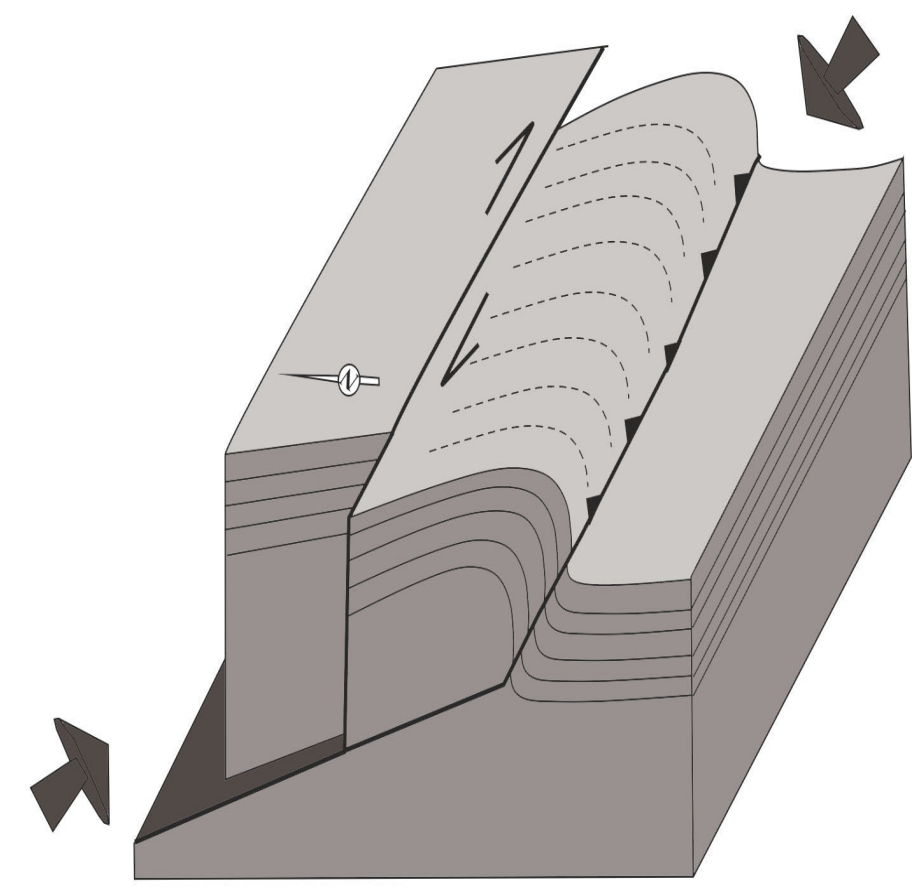

\section{Shortening axis}

Figure 5. Obliquity of major faults by report of axis of shortening.

\section{Deformation in Southern Central of Atlassic of Tunisia}

In Bou Ramli-Ben Younes-Es Stah junction (Figure 2), the major outcrops limited by faults of NE-SW and NW-SE direction. The activity of these faults in geological time shows the distensional structure and compressional structure. The slickenside of faults allows specifying the geodynamic evolution and the tectono sedimentary relation characterizing every locality.

The structural analysis and kinematics study of faults of N120-130 direction which stake the outcrops of Ben Younes-Bou Ramli-Es Stah shows the direction of stress; indeed $\sigma$ max suggests the axis of shortening of NNW-SSE and N-S of direction. This direction of axis of shortening can be connected to the state of convergence which affects allocation of North Africa. This regime of constraint is bound to an increase of the rate of convergence.

The oblique convergence between Africa plate and Europe plate is accommodated by the partition of the movement in intracratonic chains. In the southern Atlassic of Tunisia, the strike-slip faults are connected with the thrusting which shows that the axis of shortening is oblique with the major faults of NW-SE direction. The analysis of geomorphologics and kinematics study of these faults allows determining the model of strain of the various outcrops related with the activity of the faults in the subsurface.

These faults contribute to the regional reorganization of the deformation of Triassic to Quaternary and receive the strain partitioning of the oblique convergence between these two plates.

The faults are connected in subsurface and permitted the distribution of the strike-slip faults and the sinusoidal thrusting in some localities in southern Atlassic of Tunisia. Therefore, the structural study and the kinematics of these faults allow reorganization of structures and deformation in southern Atlassic of Tunisia.

\section{Discussion}

During approaching of two blocs of European and African plates, the deformation can be absorbed along the largest orogenic domain. The distribution of deformation in this domain isn't homogeny. It is accommodated by the orientation of different structures (faults and folds)

The faults transport shortening movement and accommodate party of oblique convergence to limits of system defined by the partitioning of deformation (Martinez et al., 2002 [29]). 
Related to the importance of obliquity angle of convergence vector to faults trends, the deformation will be accommodated by partitioning, producing a tranpressional deformation example of Alpine, Philippine and Sumatra faults (McCaffrey, $1992[30]$ ).

The transpressional deformation is also accommodated by the coexistence of strike-slip and thrust fault like the Alpine fault of New Zealand (Walcott, 1979 [31]; Norris et al., 1990 [32]). It also permeates the genesis of folds in echelon disposition (Richard and Cobbold, 1990 [33]; Tikoff and Peterson, 1998 [34]) observed in the transition zone of Zagros-Makran in Iran (Regard et al., 2005 [35]).

In Tunisia, different models have been proposed based on the position of the major faults and the axis of shortening.

At the North-South axis, the deformation is characterized by the predominance of extensive component on submeridian faults and a slip component on the transverse faults. The model is related to a compressive tectonic determined by extensional inheritance associated with the model of "fault propagation fold" (Creuzot et al., 1993 [15]).

The southern central Atlassic of Tunisia is characterized by overlapping structures types of "thick skinned" and by a lateral variation of structural geometry and shortening rates controlled by oblique ramps of NW-SE direction. The main thrust fault affecting Bou Ramli-Ben Younes-Es Stah junction partitions the oblique convergence during the tectonic phases and causes the genesis of major strike-slip faults. So we can propose the model of strain partitioning is under control of oblique ramp in the Gafsa Basin based on the coexistence of strike-slip faults associated with thrusting.

Whereas, in Orbata Bouhedma junction, this important compression allows the activation of these faults in reverse which explains the overlap of anticlines and synclines disappearance resulting the model of tear fault.

\section{Conclusions}

The originality of this work is the interpretation for the first time in North Africa for a model of partitioning deformation based on the surface data and the comparison among many study areas. This interpretation is related to the reactivation of directional preexisting faults during compressive phases.

Many parameters explain the choice of this model especially the obliquity direction of shortening axis and the convergence of field stress during compressive phase. This kinematics is proven by the coexistence of strike-slip and trust faults and the role of basement structures in displacement of deformation according to decollement level in Triassic series. The maximum of deformation is observed in the forelimb in the cover structures limited by the Gafsa fault.

\section{References}

[1] Decourt, J., Zonenshai, L.P., Ricou, L.E., Kazmin, V.G., Le Pichon, X., Knipper, A.L., Grandjacquet, C., Sborshchikov, I.M., Boulin, J., Sorokhtin, O., Geyssant, J., Lepvrier, C., Biju-Duval, B., Sibuet, J.C., Savostin, L.A., Westphal, M. and Lauer, J.P. (1985) Présentation de 9 cartes paléogéographiques au 1:20,000,000 s'étendant de l’Atlantique au Pamir pour la période du Lias a l’actuel. Bulletin de la Societe Geologique de France, 8, 637-652.

[2] Morelli, A. and Barrier, E. (2004) Geodynamic Map of the Mediterranean, Coordinated by Cadet, J.-P. and Funiciello, R. Commission for the Geological Map of the World.

[3] Frizon de Lamotte, D., Leturmy, P., Missenard, Y., Khomsi, S., Ruiz, G., Saddiqi, O., Guillocheau, F. and Michard, A. (2009) Mesozoic and Cenozoic Vertical Movements in the Atlas System (Algeria, Morocco, Tunisia): An Overview. Tectonophysics, 475, 9-28. http://dx.doi.org/10.1016/j.tecto.2008.10.024

[4] Martinez, C., Chikhaoui, M., Truillet, R., Ouali, J. and Creuzot, G. (1990) Le contexte géodynamique de la distension albo-aptienne en Tunisie septentrionale et centrale: structuration éocrétacée de l’Atlas tunisien. Eclogae Geologicae Helvetiae, 84, 61-82.

[5] Frizon de Lamotte, D., Saint Bézar, B., Bracène, R. and Mercier, E. (2000) The Two Main Steps of the Atlas Building and Geodynamics of the Western Mediterranean. Tectonics, 19, 740-761. http://dx.doi.org/10.1029/2000TC900003

[6] Zargouni, F. Rabia, M. C. and Abbès, C. (1985) Rôle des couloirs de cisaillement de Gafsa et de Négrine-Tozeur dans la structuration du faisceau des plis des Chotts, éléments de l'accident sud-Atlasique. Comptes rendus de l'Académie des sciences, 301, 831-834.

[7] Ben Ayed, N. (1986) Evolution tectonique de l'avant-pays de la chaîne alpine de Tunisie du début du Mésozoïque à l'actuel. Thèse d'Etat, University of Paris-Sud, Orsay.

[8] Boukadi, N. (1994) Structuration de l’Atlas de Tunisie: Signification géométrique et cinématique des noeuds et des zones 
d’interférences structurales au contact de grands couloirs tectoniques. Unpublished Thesis ès-Sciences, UniversitéTunis II, $249 \mathrm{p}$.

[9] Bouaziz, S. (1995) Etude de la tectonique cassante dans la plate-forme et l'Atlas Sahariens (Tunisie méridionale): Evolution des paléochamps de contraintes et implications géodynamiques. Unpublished Thesis ès-Sciences, Université Tunis II, $484 \mathrm{p}$.

[10] Chihi, L., Dlala, M. and Ben Ayed, N. (1984) Manifestations tectoniques synsédimentaires et polyphasées d’âge crétacé moyen dans l'Atlas tunisien central (région de Kasserine). Comptes-rendus des séances de l'Académie des sciences. Série 2, Mécanique-physique, chimie, sciences de l’univers, sciences de la terre, 298,141-146.

[11] Zargouni, F., Rabia, M.C. and Abbès, A. (1985) Rôle des couloirs de cisaillement de Gafsa et de Négrine-Tozeur dans la structuration du faisceau des plis des Chotts, éléments de l'accident sud-Atlasique. C. R. Acad. Sci (FRA), 301.

[12] Boukadi, N. (1985) Evolution géodynamique et cinématique de la zone d'interférence de l'Axe Nord-Sud et de la chaîne de Gafsa (Maknassy-Mezzouna et Jebel Bouhedma). Thèse de 3ème cycle, Univ. Louis Pasteur, Strasbourg, 143 p.

[13] Ahmadi, R., Ouali, J., Mercier, E., Mansy, J.L., Van-Vliet Lanoë, B., Launeau, P., Rhekhiss, F. and Rafini, S. (2006) The Geomorphologic Imprints of Hinge Migration in the Fault-Related Folds. A Case Study in Southern Tunisian Atlas. Journal of Structural Geology, 28, 721-728. http://dx.doi.org/10.1016/j.jsg.2006.01.004

[14] Perthuisot, V. (1978) Dynamique et pétrogenèse des extrusions triasiques en Tunisie septentrionale. Thèse Doct, Ès Science, Trav. Lab. Géol. Ecole Nor. Sup., Paris, 312 p.

[15] Creuzot, G., Mercier, E., Ouali, J. and Tricard, P. (1993) La tectogenèse atlasique en Tunisie centrale: Apport de la modélisation géométrique. Eclogae Geologicae Helvetiae, 86, 609-627. Thèse de 3ème cycle, Université de Besançon, Besançon, 163 p.

[16] Outtani, F., Addoum, B., Mercier, E., Frizon de Lamotte, D. and Andrieux, J. (1995) Geometry and Kinematics of the South Atlas Front Algeria and Tunisia. Tectonophysics, 249, 233-248.

[17] Ouali, J. (2007) Importance du réseau rhégmatique dans la tectogenèse de la Tunisie atlasique à travers l'étude de l'axe Nord-Sud. Thèse d'état, Université de Tunis El Manar, Tunis, 399 p.

[18] Bensalem, M.S., Ghanmi, M. and Zargouni, F. (2010) Modelling Genesis of Intracratonic Chains Related to Tectonics Inheritance: Case Study from Gafsa Basin (Southern Central Tunisia). Journal of Geography and Geology, 1, 58-70.

[19] Zouaghi, T., Ferhi, I., Bedir, M., Ben Youssef, M., Gasmi, M. and Inoubli, M.H. (2011) Analysis of Cretaceous (Aptian) Strata in Central Tunisia, Using 2D Seismic Data and Well Logs. Journal of African Earth Sciences, 61, 38-61. http://dx.doi.org/10.1016/j.jafrearsci.2011.05.002

[20] Saïd, A., Chardon, D., Baby, P. and Ouali, J. (2011) Active Oblique Ramp Faulting in the Southern Tunisian Atlas. Tectonophysics, 499, 178-189. http://dx.doi.org/10.1016/j.tecto.2011.01.010

[21] Amamria, S., Bensalem, M.S., Ghanmi, M. and Zargouni, F. (2011) Condition of Development of Collapse Structure in the Southern-Central Atlassic Tunisia Case Study to Gafsa Basin. Arabian Journal of Geosciences, 6, 2081-2087.

[22] Aissaoui, D. (1984) Les structures liées à l’accident sud-atlasique entre Biskra et le Jebel Manndra, Algérie: Evolution géométrique et cinématique. Thèse de 3 ème cycle, Univ. Louis Pasteur, Strasbourg.

[23] Gourmelen, C. (1984) Serrage polyphasé de paléostructures distensives dans l Axe nord-sud tunisien: le segment Bou Zer-Rhéouis. Thèse de 3 ème cycle, Univ. Grenoble I, Grenoble, 216 p.

[24] Ouali, J. (1985) Structure et évolution géodynamique du chaînon Nara-Sidi Khalif (Tunisie Centrale). Bulletin des centres de recherches Exploration-production Elf-Aquitaine, 9, 155-182.

[25] Zargouni, F. (1985) Tectonique de l’Atlas méridional de la Tunisie, évolutiongéométrique et cinématique des structures en zone de cisaillement. Thèse Doc. Es-Sci Univ. Louis Pasteur de Strasbourg et Revue des sciences de la terre de LINRST, $304 \mathrm{p}$.

[26] Zouari, H. (1995) Evolution géodynamique de l’Atlas centro-méridional de la Tunisie.Stratigraphie, analyses géométrique, cinématique et tectono-sédimentaire. Thèse Doc. Es-Sci, Univ. Tunis II, 278 p.

[27] Amamria, S., Bensalem, M.S., Mercier, E., Ghanmi, M. and Zargouni, F. (2013) Strain Partitioning Controlled by Oblique Ramp in Intracratonic Chains in Tunisia: Example of Gafsa Basin. International Journal of Geosciences, 4, 408-416.

[28] Addoum, B. (1995) L’Atlas Saharien Sud-Oriental: Cinématique des plis-chevauchements et reconstitution du bassin du Sud-Est constantinois (confins algéro tunisiens). Thèse de Doctorat, University of Paris-Sud, Orsay, 158 p.

[29] Martinez, A., Malavieille, J., Lallemand, S. and Collot, J.-Y. (2002) Partition de la déformation dans un prisme d'accrétion sédimentaire en convergence oblique: Approche expérimentale. Bulletin de la Societe Geologique de France, 173, 17-24.

[30] McCaffrey, R. (1992) Oblique Plate Convergence, Slip Vectors, and Forearc Deformation. Journal of Geophysical Research, 97, 8905-8915. http://dx.doi.org/10.1029/92JB00483

[31] Walcott, R.I. (1979) Plate Motion and Shear Strain Rates in the Vicinity of the Southern Alps. The Royal Society of New Zealand Bulletin, 18, 5-12. 
[32] Norris, R.J., Koons, P.O. and Cooper, A.F. (1990) The Obliquely-Convergence Plate Boundary in the South Island of New Zealand. Journal of Structural Geology, 12, 715-725. http://dx.doi.org/10.1016/0191-8141(90)90084-C

[33] Richard, P. and Cobbold, P.R. (1990) Experimental Insights into Partitioning of Fault Motions in Continental Convergent Wrench Zones. Annales Tectonicae, 4, 35-44.

[34] Tikoff, B. and Peterson, K. (1998) Physical Experiments of Transpressional Folding. Journal of Structural Geology, 20, 661-672.

[35] Regard, V., Bellier, O., Thomas, J.C., Bourlès, D., Bonnet, S., Abbassi, M.R., Braucher, R., Mercier, J., Shabanian, E., Soleymani, S. and Feghhi, H. (2005) Cumulative Right-Lateral Fault Slip Rate across the Zagros-Makran Transfer Zone: Role of the Minab-Zendan Fault System in Accommodating Arabia-Eurasia Convergence in Southeast Iran. Geophysical Journal International, 160, 1-25. 